\title{
Load Transfer On Bored Pile Foundation Instrumented With Fiber Optic And Concrete Quality Analysis
}

\author{
K. M. Setianto ${ }^{1 *}$, C. L. G. Swan' ${ }^{2}$, P. P. Rahardjo ${ }^{3}$ \\ ${ }^{1 * 2,3}$ Faculty of Engineering, Universitas Katolik Parahyangan, Jl. Ciumbuleuit No. 94, \\ Bandung, Indonesia, 40141. \\ Email : 1*kevinmartandisetianto@gmail.com
}

A R T I C L E IN F O

\section{Article History :}

Article entry : 22-02-2021

Article revised : 10-03-2021

Article received : 13-08-2021

Keywords :

Bored Pile, Concrete, Foundation, Fiber Optic, Modulus of Elasticity, Strain.

IEEE Style in citing this article : [4] D. V. Karandikar, "Challenges to Quality Control in Bored Cast-In-Situ Piling in Growing Urban Environment," Indian Geotech. J., vol. 48, no. 2, pp. 360-376, 2018, doi: $10.1007 / s 40098-017-0277-z$

\section{Introduction}

A B S T R A C T

The problem in the construction method of the bored pile is the contamination of mud or the other contaminant that can cause the modulus of elasticity of concrete to decrease. This research determines the modulus of concrete on a bored pile foundation instrumented with fiber-optic (FO) with a manual calculation based on strain data during loading test, validated with the results of research in the laboratory and numerical analysis. Fiber optic was used to measure the strain along with the pile during the loading test. The bored pile foundation is divided into 12 segments with the same strain characteristics, and then the modulus value is calculated. The result is the modulus value of each segment is different, and the value of the modulus changes along with the increase in strain; the modulus will decrease as the strain increases. This differs from the theory that the modulus has a fixed value approximated by empirical equations. Made a cylindrical concrete sample on both sides, which installed a FO to record the strain during the loading test. The result is true that the modulus is not constant but decreases as the strain increases. It is shown in the result of analysis to fiber-optic measurement data. Created a model in Plaxis2D for validation, and the results are not much different from the manual calculation.

In the design process of a bored pile foundation, usually, the modulus elasticity of the concrete used will always be the same or constant in all loading conditions, which can be approximated by the equation $33 \mathrm{w}^{1,5} \sqrt{ } \mathrm{f}^{\mathrm{n}} \mathrm{c}$ psi[1] or other equations $4700 \sqrt{ } \mathrm{f}^{\mathrm{n}} \mathrm{c}[2]$. When viewed from the two equations, the modulus of elasticity of concrete value solely depends and is influenced by the concrete's quality, which is symbolized by the value of $\mathrm{f}_{\mathrm{C}} \mathrm{c}$. This study wants to examine the actual conditions in the field when the bored pile foundation is loaded, whether, 
indeed, the modulus of concrete is always the same.

Another problem that often occurs is that the modulus of concrete is considered the same or homogeneous from the top to the bottom of the bored pile foundation. The process of working on a bored pile foundation brought in a field full of uncertainty and technical problems, so the construction method greatly affects the performance of the bored pile foundation [3][4]. One example of the problem is the contamination of the groundwater level, soil from drilling, and sediment deposits from the slurry at the bottom of the borehole which will be mixed with wet concrete when the casting process isn't done with the correct method [5][6] and as a result, when it was dry, contaminated concrete becomes defected and the quality changes; generally the changes that occur will not be the same from the top to the bottom of the bored pile foundation. The quality of concrete, in this case later, is described by its modulus of elasticity.

Damage to the pile will be difficult to check by directly looking at the physical form of the pile foundation because the foundation has been built below the ground level. However, we can overcome this by doing in situ empirical testing such as an axial static loading test on an instrumented bored pile [7][8][9][10]. The difference in the quality of the concrete can be read well by the fiber optic wire instrumentation, which is indicated by the strain of the concrete at the depth where the damage will change very drastically. The purpose of this study is to determine the modulus of elasticity of concrete on a bored pile foundation instrumented with fiber optic wire with a manual calculation based on strain data along with the pile during static loading test, which is validated with the results of research in the laboratory and numerical analysis using Plaxis 2D software.

\section{Literature Review}

Bored pile foundation is the type of deep foundation that is constructed in the field project directly. There are so many reasons for us to use bored pile foundation as our building foundation system are (1) the consistency of soil in the top is soft to medium soft, (2) there is an inclined workload, (3) bored pile foundation has the higher lateral capacity, and (4) bored pile foundation has the higher uplift capacity [5]. After the bored pile foundation is constructed, we must check the actual capacity of the pile, and the alternative we can do is a loading test. There are two types of loading tests, static and dynamic loading tests, but in this study, we use the static loading test data in the form of strain data and the bored pile during the loading test. To get the strain data, we usually install some instruments in the testing pile. In the past, we often use Vibrating Wire Strain Gauge (VWSG), but now we can use fiber optic wire to do this. 
The use of fiber optic wire as instrumentation for a bored pile foundation is still very rare in Indonesia. Generally, a vibrating wire strain gauge (VWSG) planted on the foundation is used [11]. One of the main advantages of a fiber optic wire is that it can read the strain along with the pile continuously with a reading interval of only $4 \mathrm{~cm}$, unlike the VWSG, which can only read at the depth at which the VWSG is installed. Therefore, fiber optic wires will be very sensitive and accurately detect when there is a change in strain in a segment of the foundation or other civil structures [12][13][14]. The fiber optic wire is installed on the reinforcing steel for the foundation of the bored pile with a loop system, which means that it is installed starting from the north side at the head of the pile, pulling it up to the pile leg then continuing to cross to the bottom of the south side and pulling up to the head of the pile (Side A-B in Figure 1); likewise mounted on the west and east sides (Side C-D in Figure 1). On very deep pile foundations, the use of fiber optic wires as instrumentation will be more efficient than VWSG because to produce a good strain reading along the pile requires a lot of VWSG to be installed [5], the process of reading the strain with a reading tool for fiber optic wire is also simpler. It can be seen in Figure 2 that the strain reading with a fiber optic wire is not much different from VWSG [15]. We can see in Figure 2, the value of $\mathrm{R}^{2}$ is close to the value of 1 , which means from the statistical view, the data that we compare in the chart is very close or similar to each other.

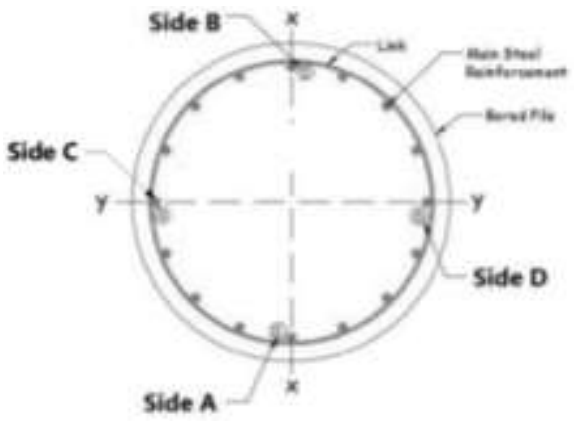

(a)

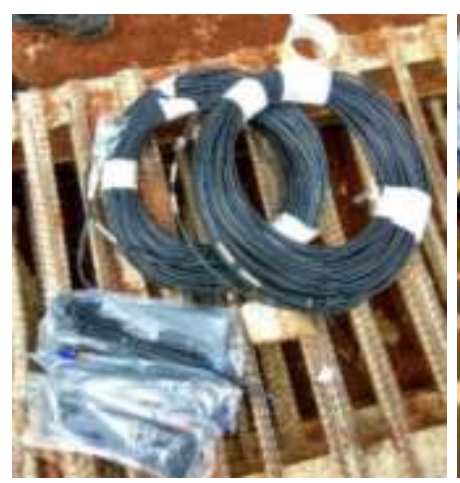

(b)

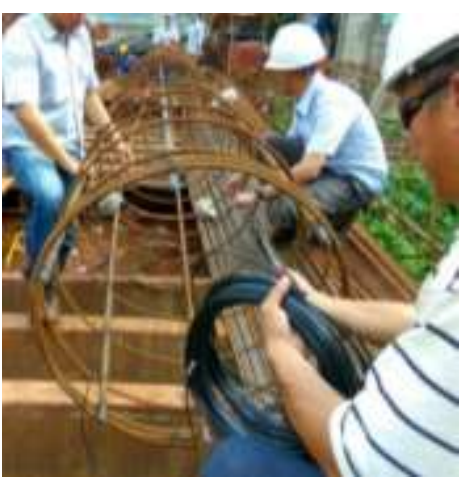

(c)

Source $\quad$ : C. Lauw, et al, $2017[10]$

Figure 1. Illustration of Installation of Fiber Optic Wire in Bored Pile Foundation,

(a) The Cross-Section of Bored Pile Foundation Instrumented with Fiber Optic Wire, (b) Rolled Fiber Optic Wire Before Installation, and (c) The Installation of Fiber Optic Wire on Bored Pile Reinforcement 

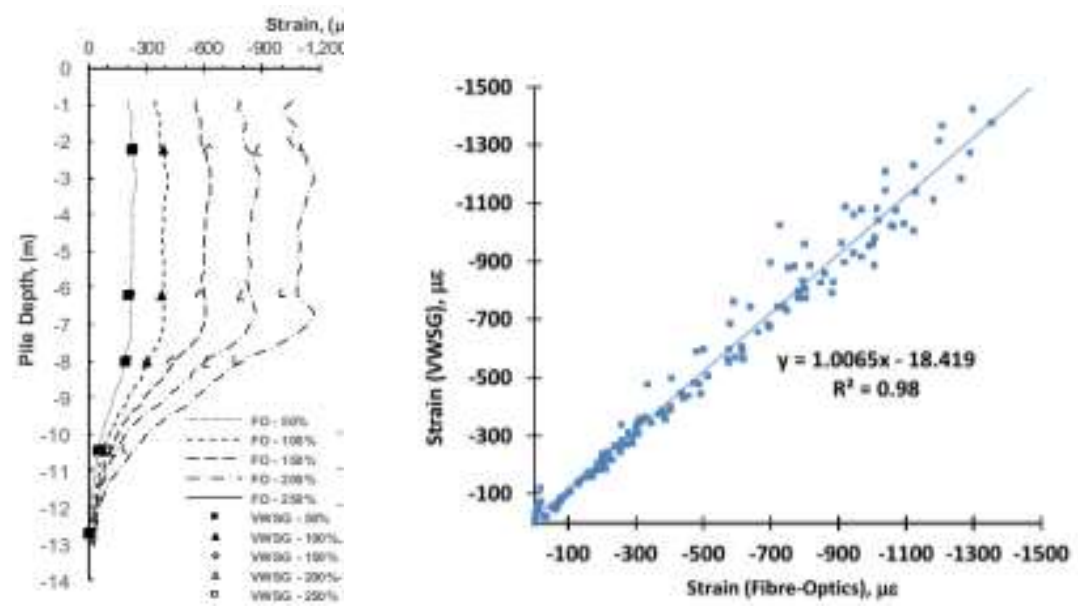

Figure 2. Comparison of Strain Reading Results from Fiber Optic and VWSG [15]

There are two strain reading systems using fiber optic wire. The first is Brillouin Optical Time Domain Reflectometer/BOTDR, and the second is Brillouin Optical Time Domain Analysis/BOTDA [16][17][18]. The way it works with the BOTDR system is by firing light from one end of the wire, then due to strain and/or temperature changes, Brillouin scattering occurs where some of the light is scattered and returns to the laser source. The light spectrum analysis from Brillouin scattering will determine how much strain and/or temperature changes have occurred. Analyzing the time of the return of scattered light will get information on which strain occurs at which location.

The BOTDA system works by firing two opposite lights from either end of the fiber optic wire. Pulse wave light is fired from one end then propagates along the fiber optic wire. Simultaneously, continuous wave (CW) light is fired in the opposite direction, propagating along the fiber optic wire.

\section{Research Method}

This research is based on a case study of a high-rise building construction project in the Province of Jakarta, Indonesia. The data held is actual data measured directly from the field in pile displacement and distribution of strain along a pile measured by a fiber optic wire. A hand calculation was carried out from these data to find the modulus of elasticity of concrete in a pile in every segment and every loading stage. These calculations are then validated with the results of research in the laboratory and numerical analysis with Plaxis 2D software.

\subsection{Hand Calculation to Find Modulus Elasticity of Concrete (From Actual Data)}

The first step is to divide the pile into several segments according to the similarity of the strain characteristics, which the author justifies. The pile is divided into 12 segments, but 
what is discussed in this research is Segment 3, Segment 4, Segment 5, and segment 11. Figure 3 shows the strain data along with the pile for each loading stage and the division of the pile into 12 segments. To calculate the modulus of elasticity of concrete, a simple equation is used for the relationship between strain and stress acting on the pile head from the static loading test, which is then transferred along the pile foundation. The compressive design strength of concrete is $30 \mathrm{MPa}$, the pile diameter is $1 \mathrm{~m}$, the pile length is $42 \mathrm{~m}$, the design load is 400 tons, and the static load test was conducted up to $260 \%$ from the design load.

\section{AXIAL STRAIN DISTRIBUTION}

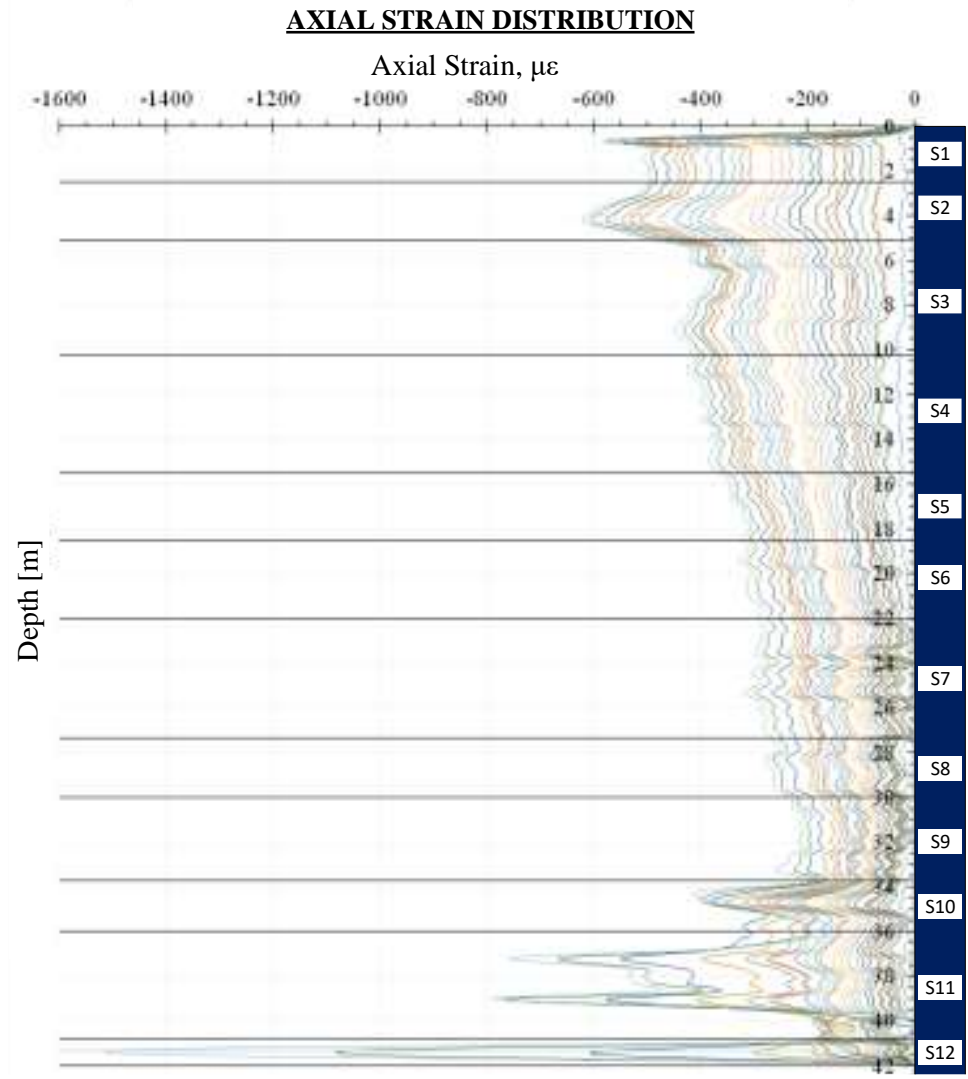

Source: Author's Documentation

Figure 3. Strain Along with the Bored Pile

\subsection{Laboratory Testing}

He made concrete cylinder samples with a diameter of $15 \mathrm{~cm}$ and a height of $30 \mathrm{~cm}$ with a compressive strength design of $30 \mathrm{MPa}$. On two sides of the concrete, installed a fiber optic wire was to measure the strain on the sample during axial load compression test using a manual testing machine which was carried out when the concrete was 28 days old [19]; installed on two sides to review the eccentricity of the load. The fiber optic wire is installed using epoxy glue to blend with the cylindrical concrete sample. The axial loading is carried out in stages every 3 tons until the concrete sample break. Fiber optic wire can read the strain on a cylindrical 
Concrete sample every $4 \mathrm{~cm}$ so that the sample will get 7 points of strain reading.
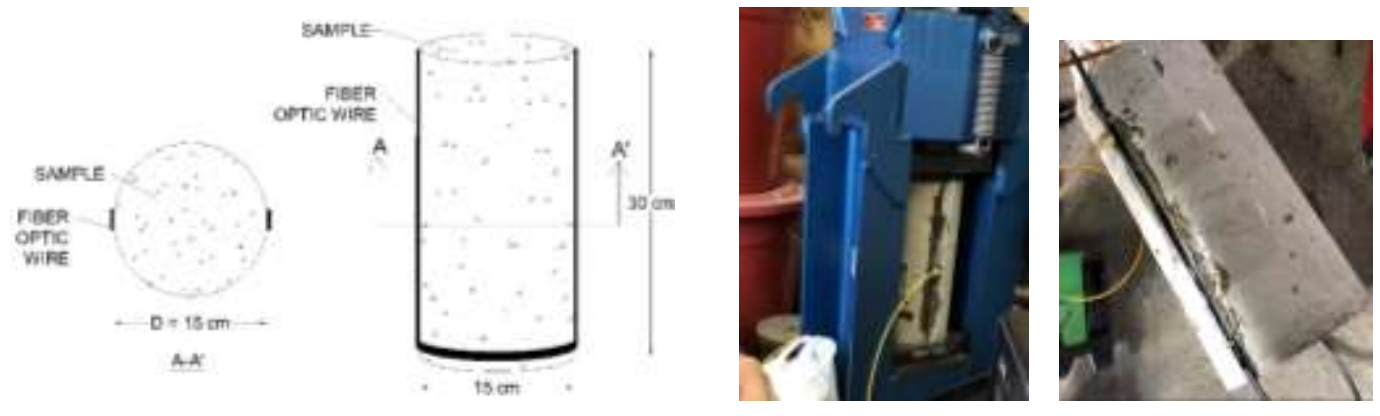

Source: Author's Documentation

Figure 4. Installation of Fiber Optic Wire in Concrete Cylinders

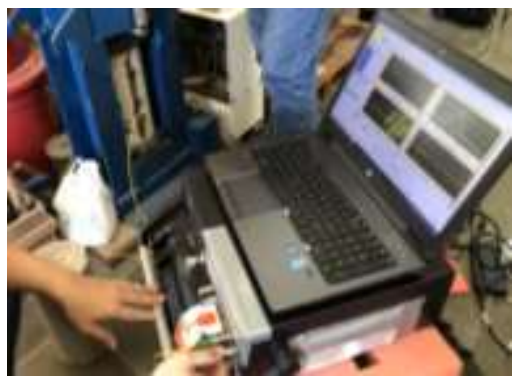

Source: Author's Documentation

Figure 5. Strain Measurement of Concrete Cylinder during Axial Compression Load

\subsection{Numerical Analysis Using 2D Plaxis Program}

Modeling is carried out in finite element method based software because the finite element method can describe the behavior of soil and other structures when there is a change in stress and strain so that it can model the behavior of elements in more detail, especially those related to the stages of stress-strain change [20][21]. Plaxis 2D is one of the many software based on the finite element method.

In this study, modeling is made in Plaxis 2D to see the value of the modulus of elasticity of the concrete on the bored pile foundation when a load increment occurs during the static loading test. The Axysimmetry model with Mohr-Coulomb soil constitutive law is used, and undrained conditions of cohesive soils are modeled using the Undrained A model. The Undrained A model used effective shear strength parameters c', $\phi$,' and effective stiffness parameters E' ${ }_{50}$ dan $v$ '. The type of material is undrained and analyzed in the context of effective stress, and groundwater levels are taken into account. Undrained A is suitable for modeling the condition of undrained soil in the finite element method because its effective stress influences soil behavior. In addition, Undrained A can better predict the amount of excess pore pressure 
and the increase in shear strength of the cohesive soils during the consolidation process [22][23]. Mohr-Coulomb soil constitutive law is well suitable for analyzing geotechnical structures [24][25][26]. Soil parameters are obtained with empirical correlation from $\mathrm{N}_{\text {SPT }}$ value and the result of geotechnical laboratory testing that we can see in Table 1. In Table 1, we can see that there are 11 layers of soil. In the first seven layers, the soil type is silty clay, with the $\mathrm{N}_{\text {SPT }}$ value varied from 3 to 7 . At depth $29 \mathrm{~m}$ until the tip of the bored pile foundation, there is a very dense sand layer with an $\mathrm{N}_{\mathrm{SPT}}$ value of 60 , so this bored pile foundation theoretically must have very high tip resistance.

Table 1. Soil Parameters for Numerical Analysis in Plaxis 2D

\begin{tabular}{|c|c|c|c|c|c|c|c|c|c|c|}
\hline Segment & Dept & th $[\mathrm{m}]$ & Soil Type & $\mathbf{N}_{\text {SPT }}$ & $\mathbf{S}_{\mathrm{u}}[\mathrm{kP}$ & $c^{\prime}[\mathrm{kPa}]$ & $\phi^{\prime}\left[{ }^{\circ}\right]$ & $E_{u}[\mathrm{kPa}]$ & $\mathbf{E}^{\prime}[\mathrm{kPa}]$ & $k[\mathrm{~cm} / \mathrm{s}]$ \\
\hline 1 & 0 & -3 & lty Clay $\mathrm{CH}$ & 4 & 32 & 6 & 25 & 9600 & 6720 & $1,00 \mathrm{E}-06$ \\
\hline 2 & 3 & -6 & $\mathrm{I}$ & 7 & 5 & 1 & 26 & 168 & 11760 & $1,00 \mathrm{E}-0$ \\
\hline 3 & 6 & -9 & Silty & 3 & 24 & 4 & 25 & 7200 & 5040 & $1,00 \mathrm{E}-\mathrm{C}$ \\
\hline 4 & 9 & -18 & $\mathrm{Si}$ & 3 & 24 & 4 & 24 & 7200 & 5040 & $1,00 \mathrm{E}-06$ \\
\hline 5 & 18 & -22 & Silty & 7 & 70 & 14 & 26 & 24500 & 17150 & $1,00 \mathrm{E}-0$ \\
\hline 6 & 22 & -24 & Silty & 14 & 14 & 28 & 30 & 49000 & 34300 & $8,00 \mathrm{E}-\mathrm{C}$ \\
\hline 7 & 24 & -27 & Silt & 10 & 10 & 20 & 29 & 35000 & 24500 & $8,00 \mathrm{E}$ \\
\hline 8 & 27 & -29 & Clay & 28 & 280 & 56 & 31 & 98000 & 68600 & $7,00 \mathrm{E}-07$ \\
\hline 9 & 29 & -44 & & 60 & $\mathrm{~N}$ & $\mathrm{~N} / \mathrm{t}$ & 4 & 60 & 00 & 1, \\
\hline 1 & 44 & -52 & Silty Clay CH & 30 & 240 & 30 & 31 & 66000 & 46200 & $7,00 \mathrm{E}-0$ \\
\hline 1 & 52 & -60 & Sand SM & 60 & N/A & N/A & 47 & 60000 & 60000 & $1,00 \mathrm{E}-\mathrm{C}$ \\
\hline
\end{tabular}

Source: Author's Documentation

Before the concrete modulus of elasticity from numerical analysis with Plaxis $2 \mathrm{D}$ is used for validation, must calibrated the modeling in Plaxis first with actual data in the field, namely calibrated against pile displacement and strain distribution along with the pile when it is loaded. The strain distribution calibration is carried out in 3 loading stages, namely $200 \%$, $200 \%$, and $240 \%$ from the design pile-working load. The results can be seen in Figure 6 and Figure 7, which state that the modeling in Plaxis 2D is well calibrated as evidenced by the output that is very close to the actual data, both pile axial movement and strain that occurs along with the pile so that the concrete modulus of elasticity values which result from numerical analysis with Plaxis 2D software can be used to validate the results of hand calculations for concrete modulus of elasticity calculations along the bored pile foundation. 


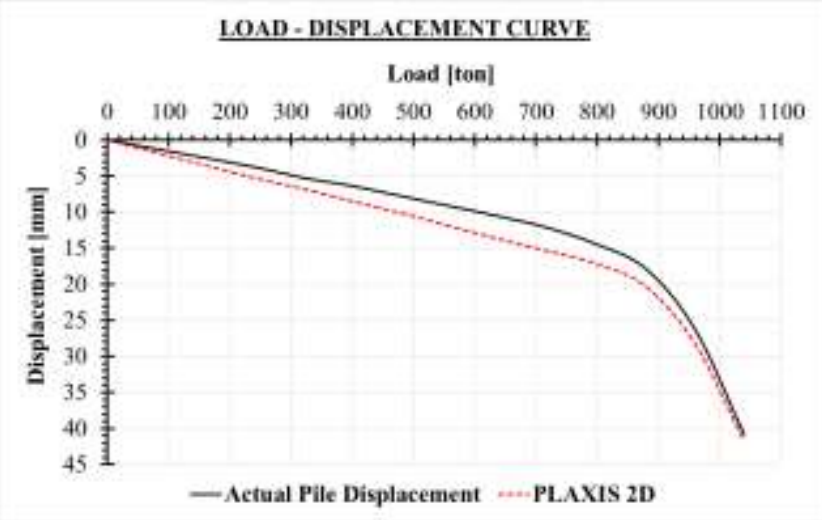

Source: Author's Documentation

Figure 6. Comparison of Actual Load-Displacement Curve with Numerical Analysis Results Using Plaxis 2D Software
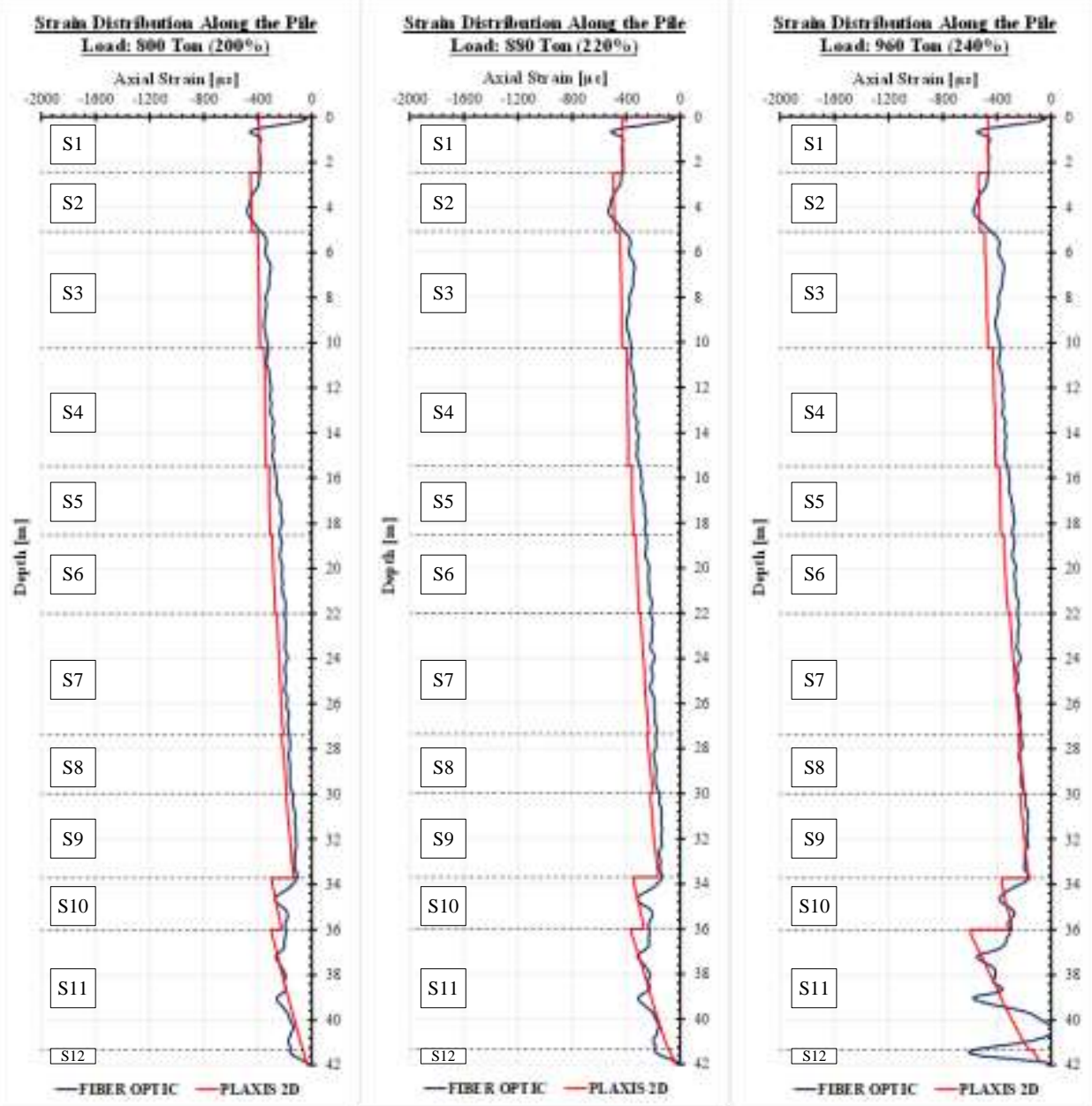

Source : Author's Documentation

Figure 7. Comparison of Actual Strain Distribution Along with the Pile with Numerical Analysis Results Using Plaxis 2D Software 


\section{Results and Discussions}

The manual calculation of the modulus of elasticity of concrete can be seen in Figure 8 and Figure 9. From these data, it appears that the modulus of elasticity of concrete on the pile foundation is not the same in each segment. The worst modulus of elasticity of concrete is found in Segment 11, where the modulus of elasticity of concrete can reach only $4000 \mathrm{MPa}$, this is very far from the initial segments or the modulus of elasticity of the design concrete which can be approximated by the equation $4700 \sqrt{f^{n}}{ }_{c}$ [2]. Using this approach, with the $f_{c}$ value of 30 $\mathrm{MPa}$, then the magnitude of the modulus of elasticity of concrete theoretically amounted to $25700 \mathrm{MPa}$, whereas that occurs in Segment 11, the lowest is only about $4000 \mathrm{MPa}$. This means that the modulus of elasticity of concrete is only about $15 \%$ of the theoretical modulus calculated by the equation $4700 \sqrt{ } \mathrm{f} c$. There is a strong suspicion that the concrete in this segment has been contaminated by contaminants, which could be mud, water, or other contaminants.

Another thing that can obtained from these data is that the modulus of concrete is not the same or constant for each loading stage. As explained in the previous paragraph, the modulus value of concrete can be approximated by the equation $4700 \sqrt{ } \mathrm{f}^{\mathrm{c}} \mathrm{c}$. Its constant value does not change; however, based on hand calculation, the modulus value of concrete can be approximated changes with increasing strain. That means the modulus value also depends on the strain that occurs. This will be validated with laboratory test results and numerical analysis in the Plaxis 2D software.
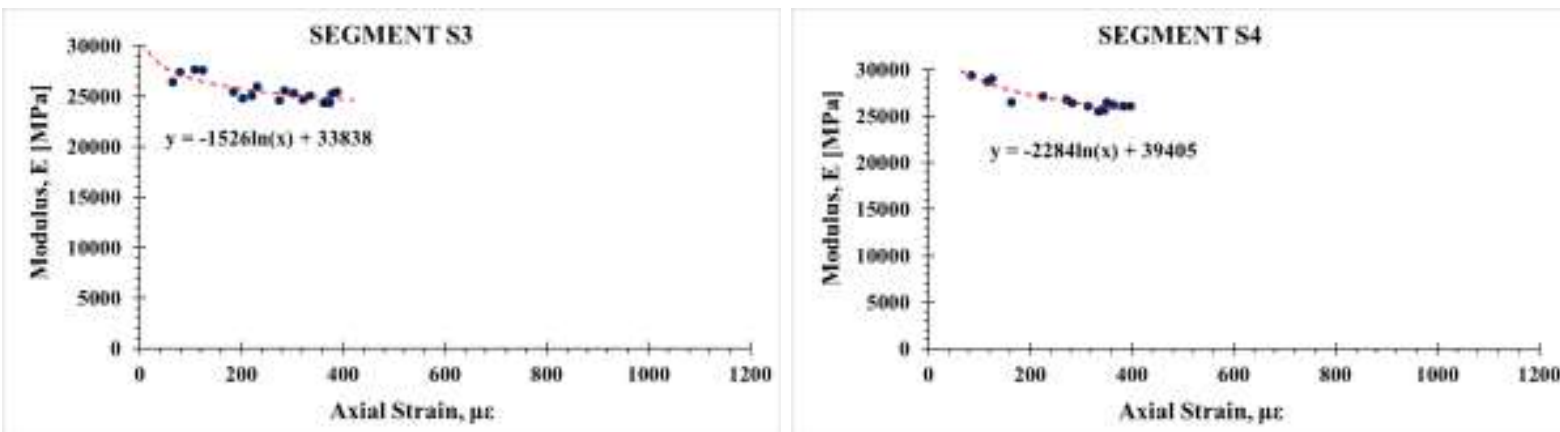

Source : Author's Documentation

Figure 8. Actual Modulus of Elasticity - Axial Strain Curve Segment 3 and Segment 4 

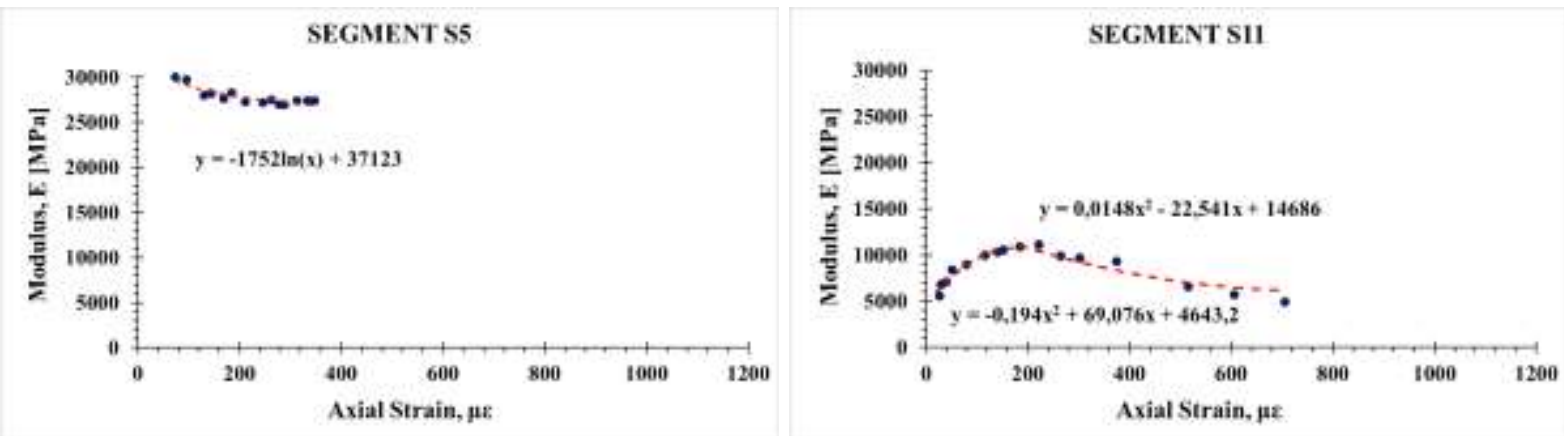

Source : Author's Documentation

Figure 9. Actual Modulus of Elasticity - Axial Strain Curve Segment 5 and Segment 11

Data in Figure 10b is the raw data of the strain reading along the fiber optic wire to calculate the value of the concrete's modulus and the concrete cylinder samples. The method used is to divide the concrete cylinder samples into four small segments and then calculate each segment's modulus. The segments can be seen in Figure 10a. The modulus value can be calculated using Hooke's Law with the same stress value along the concrete cylinder samples originating from the load applied to the top of the sample. The strain value used is the strain in the middle of each segment.

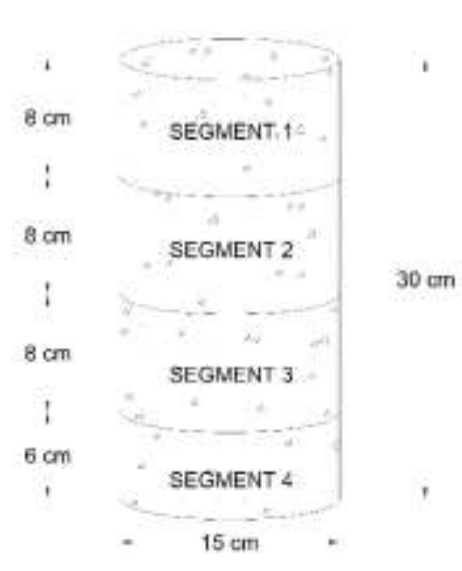

(a)

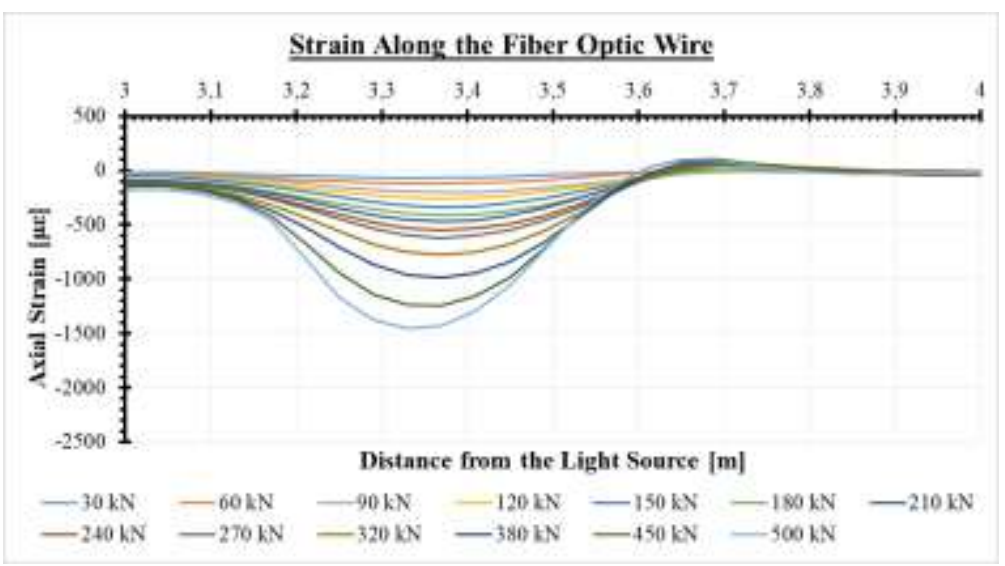

(b)

Source : Author's Documentation

Figure 10. (a) Segment Division of Concrete Cylinder Samples, (b) Reading of Strains Along the Fiber Optic Wire in Concrete Cylinder Sample 

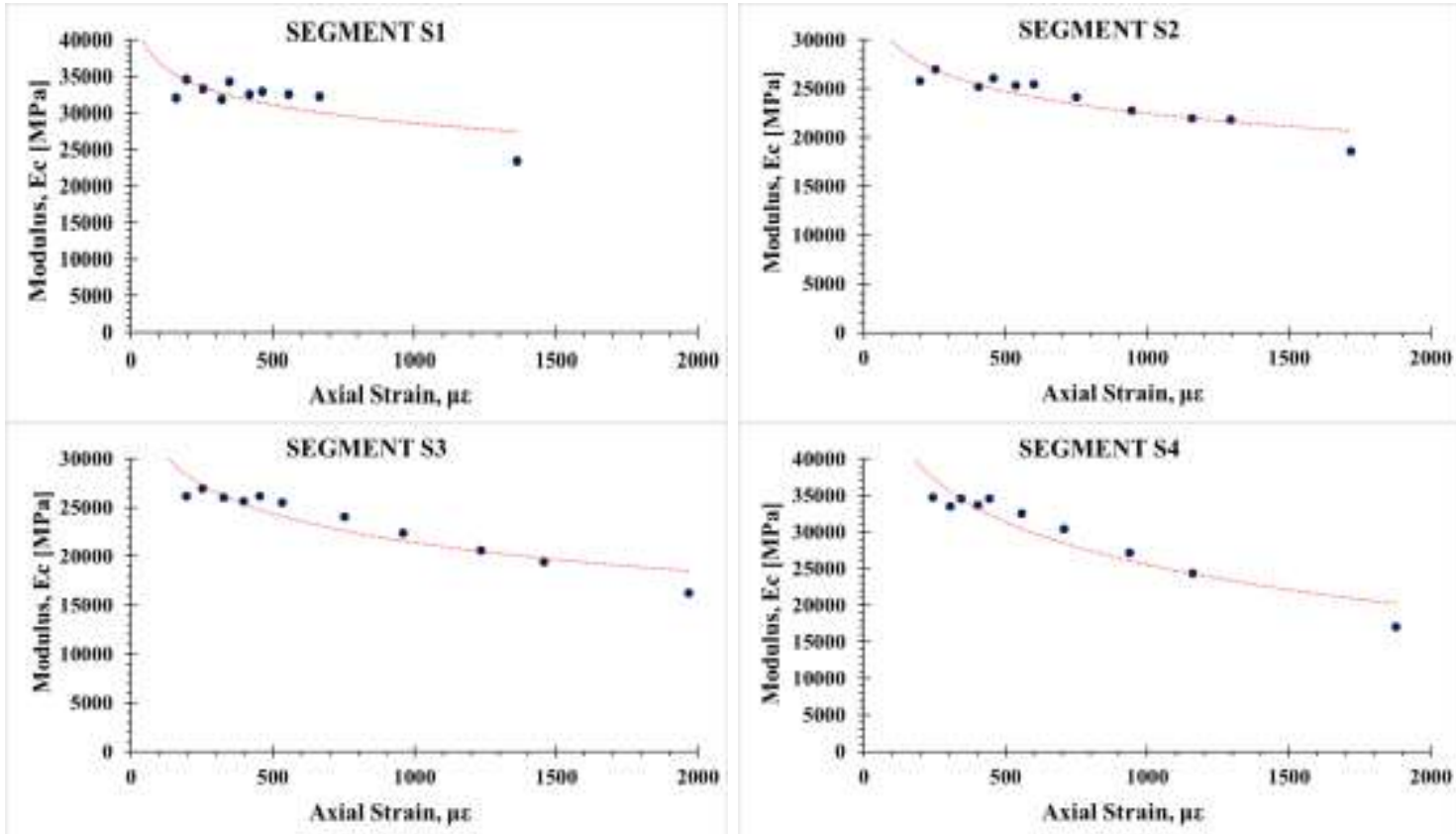

Source : Author's Documentation

Figure 11. Modulus of Elasticity - Axial Strain Curve from Laboratory Testing

From the data in Figure 11, the modulus value of concrete cylinder samples is not always the same, but the value changes with increasing axial strain in the concrete sample. Then the results of the fiber optic wire strain data analysis have been validated correctly from laboratory data. This contradicts the assumption often used, namely that the modulus value of concrete will always be the same, one approach often used is $4700 \sqrt{ } f^{n}$. With $f_{c}{ }_{c}$ value used is $30 \mathrm{MPa}$, the modulus of the concrete samples should always be the same, which is equal to $25742 \mathrm{MPa}$. However, the fact is the modulus of elasticity of concrete is strain-dependent.

Modulus of Elasticity of Concrete - Axial Strain Curve

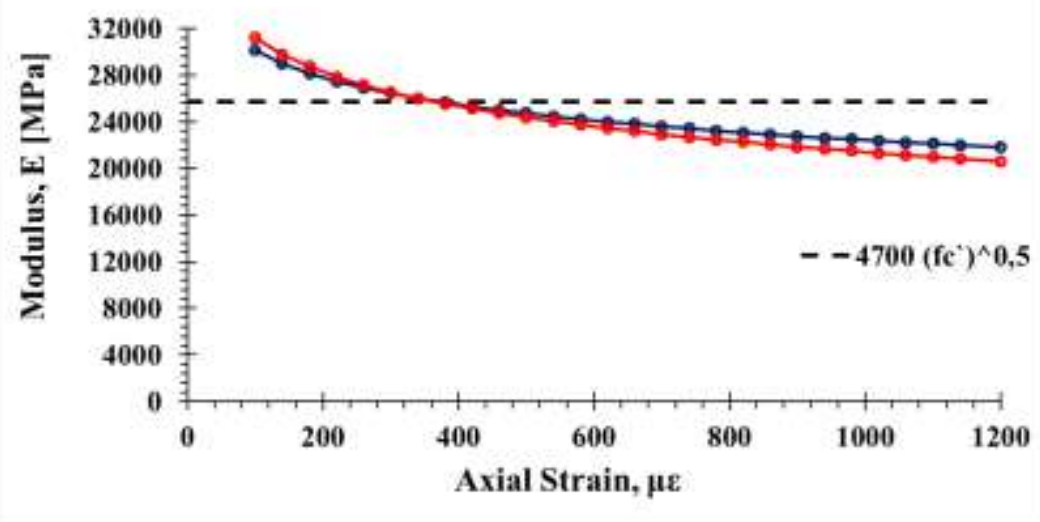

Source : Author's Documentation

Figure 12. Comparison of the Modulus of Elasticity from Laboratory Testing with the Results of Empirical Equation $4700 \sqrt{ } \mathrm{f}^{n}{ }_{\mathrm{c}}$ 
The black dotted line in Figure 12 is a linear value that does not change (it does not depend on the stress value in the concrete cylinder samples), resulting from the equation $4700 \sqrt{ } f^{n}$. The relationship line then penetrates this line between the modulus and axial strain in segment 2 and 3 obtained from laboratory testing. From there, it can be seen that the same modulus of elasticity of concrete value, or the $4700 \sqrt{ } f^{n}$ approaches is used, will be safe to use when the value that occurs in concrete is still relatively small. However, when the strain increases, the actual modulus value occurring in concrete - based on laboratory test data becomes smaller than the initially assumed modulus elasticity of concrete value. This can be seen from the modulus-strain relationship curve that crosses the $4700 \sqrt{ } f^{n}{ }_{c}$ line, so that it must be of greater concern when the strain that occurs in the concrete is getting bigger. What should be noted is that this is still happening on a laboratory scale; for its application in civil engineering projects, must consider several other things.
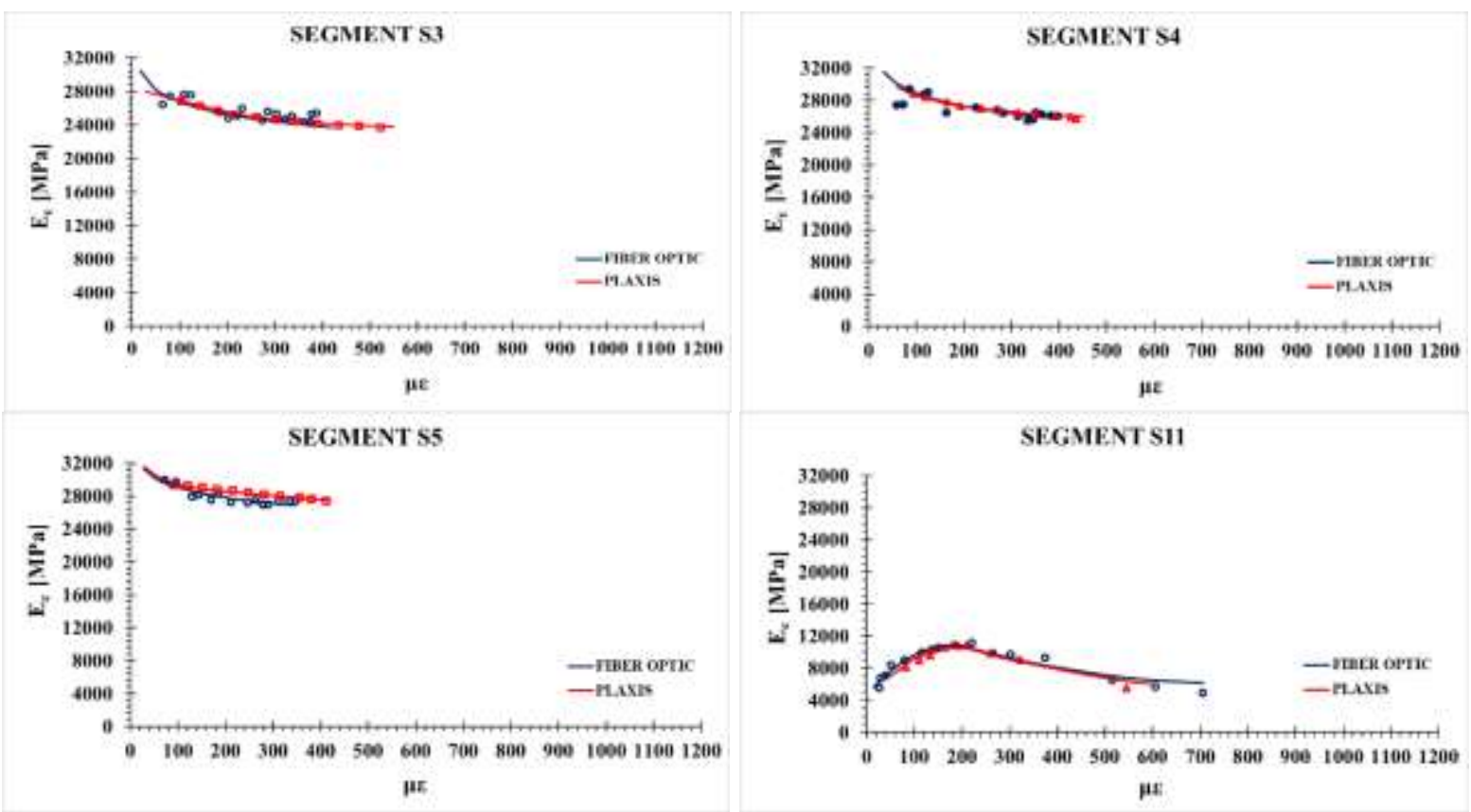

Source : Author's Documentation

Figure 13. Comparison of the Actual Modulus of Elasticity (Fiber Optic) and from Numerical Analysis with 2D Plaxis

Based on the data in Figure 13, it can be seen that it is true that the modulus value of concrete changes with the increase in the value of strain on the concrete body. The modulus value used for numerical analysis is not much different from the modulus value calculated based on fiber optic wire data. In segment 11 , the modulus value is also validated. The lowest is around $4000 \mathrm{MPa}$. When compared with modulus data from laboratory test results, at the same 
strain, which is about $50 \mu \varepsilon$, the modulus of concrete can reach $29.000 \mathrm{MPa}$. That means the modulus in Segment 11 and Segment 12 is reduced by more than $85 \%$, or only about $15 \%$ remains.

In addition, the modulus values, which are not homogeneouseous along with the pile, and can even change very far, have also been validated by the results of numerical analysis with the Plaxis 2D program (Figure 7). It can be seen that the modulus value along the pile foundation is not always the same and tends to change. There is a strong suspicion that this is due to the construction method carried out in the field during the casting process, causing the concrete at a certain depth to become damaged because it has been contaminated.

\section{Conclusion and Suggestion}

\subsection{Conclusion}

1. The test results of the actual instrumented bored pile foundation loading (with fiber optic), laboratory test results, and numerical analysis results, consistently show that the determination of the modulus of elasticity of concrete with empirical equations with constant values is less precise.

2. The modulus of elasticity of concrete varies with the amount of normal strain that occurs. There is a tendency that the modulus of elasticity of concrete decreases with the increase in a normal strain.

3. The modulus value of concrete on the bored pile foundation is not homogeneous along with the pile. This can be due to the construction method and the amount of axial strain at each depth.

4. Based on laboratory test results, the $4700 \sqrt{ } f^{n} \mathrm{c}$ equation to calculate the modulus value is smaller than the actual modulus value when the strain that occurs in concrete is still relatively small. Meanwhile, if the strain gets bigger, the value will be lower than the actual modulus of elasticity value.

\subsection{Suggestion}

From this research, our suggestion is (1) fiber-optic wires are installed on the four sides of the concrete cylinder samples so that can measured changes in strain more precisely, and (2) it is necessary to consider the application of research results in the laboratory which states that the modulus value changes along with changes in strain in relation to the bored pile foundation design process. 


\section{References}

[1] A. Pauw, "Static Modulus of Elasticity of Concrete as Affected by Density," Am. Concr. Inst., vol. 6, no. 5, pp. 679-687, 1960.

[2] 2847:2013 SNI, "Persyaratan Beton Struktural untuk Bangunan Gedung," Bandung Badan Stand. Indones., pp. 1-265, 2013.

[3] F. Abdrabbo and H. Abouseeda, "Effect of construction procedures on the performance of bored pile," ASCE Deep Found. J., pp. 1438-1454, 2002.

[4] D. V. Karandikar, "Challenges to Quality Control in Bored Cast-In-Situ Piling in Growing Urban Environment," Indian Geotech. J., vol. 48, no. 2, pp. 360-376, 2018, doi: 10.1007/s40098-017-0277-z.

[5] Deep Foundation Research Institute, Manual Pondasi Tiang, 5th ed. Bandung: Universitas Katolik Parahyangan, 2017.

[6] F. Abdrabbo and H. Abouseeda, "Effect of Construction Procedures on the Performance of Bored Piles,” pp. 1438-1454, 2002, doi: 10.1061/40601(256)103.

[7] B. H. Hertlein, "Development of Nondestructive Small- Strain Methods for Testing Deep Foundations : A Review," Transp. Res. Rec., pp. 15-20, 1991.

[8] F. Rausche, G. E. Likins, and S. R. Kung, "Pile Integrity Testing and Analysis," Applications of Stress-Wave Theory to Piles. pp. 613-617, 1992.

[9] G. Likins, F. Rausche, R. Miner, and M. Hussein, "Verification of deep foundations by NDT methods," Design and Performance of Deep Foundations: Piles and Piers in Soil and Soft Rock. pp. 76-90, 1993.

[10] C. Lauw, P. P. Rahardjo, A. Arafianto, and A. Wirawan, "Strain Measurement and Investigation of the Concrete Quality Uniformity of a Bored Pile Foundation Using Fiber Optic Sensors Under Static Loading Test," no. 2, pp. 2-11, 2017.

[11] A. Sprince and L. Pakrastinsh, "Helical pile behavior and load transfer mechanism in different soils," 10th Int. Conf. Mod. Build. Mater. Struct. Tech., pp. 1174-1180, 2010.

[12] H. Mohamad, K. Soga, A. Pellew, and P. J. Bennett, "Performance Monitoring of a Secant-Piled Wall Using Distributed Fiber Optic Strain Sensing," J. Geotech. Geoenvironmental Eng., vol. 137, no. 12, pp. 1236-1243, 2011, doi: 10.1061/(asce)gt.1943-5606.0000543. 
[13] H. Mohamad et al., "Monitoring Tunnel Deformation Induced by Close-Proximity Bored Tunneling Using Distributed Optical Fiber Strain Measurements,” no. Fmgm, pp. 1-13, 2007, doi: 10.1061/40940(307)84.

[14] H. Mohamad, K. Soga, P. J. Bennett, R. J. Mair, and C. S. Lim, "Monitoring Twin Tunnel Interaction Using Distributed Optical Fiber Strain Measurements," J. Geotech. Geoenvironmental Eng., vol. 138, no. 8, pp. 957-967, 2012, doi: 10.1061/(ASCE)gt.1943-5606.0000656.

[15] H. Mohamad, B. P. Tee, M. F. Chong, and K. A. Ang, "Investigation of shaft friction mechanisms of bored piles through distributed optical fiber strain sensing," ICSMGE 2017 - 19th Int. Conf. Soil Mech. Geotech. Eng., vol. 2017-Septe, no. Figure 2, pp. 28292832,2017

[16] W. Thunderbolt, "Distributed Strain and Temperature Sensor BOTDA / BOTDR With Thunderbolt Interface I-user Manual.”

[17] B. Liu, D. Zhang, and P. Xi, "Mechanical behaviors of SD and CFA piles using BOTDAbased fiber optic sensor system: A comparative field test study," Meas. J. Int. Meas. Confed., vol. 104, pp. 253-262, 2017, doi: 10.1016/j.measurement.2017.03.038.

[18] H. Ahmad, S. N. Aidit, and Z. C. Tiu, "Multi-wavelength Praseodymium fiber laser using stimulated Brillouin scattering," Opt. Laser Technol., vol. 99, pp. 52-59, 2018, doi: 10.1016/j.optlastec.2017.09.044.

[19] SNI1974-2011, "Cara Uji Kuat Tekan Beton dengan Benda Uji Silinder,” Badan Stand. Nas. Indones., p. 20, 2011.

[20] R. Brinkgreve, "Plaxis finite element code for soil and rock analyses," 2002.

[21] R. B. J. Brinkgreve, E. Engin, and W. M. Swolfs, "PLAXIS 2016 3D Tutorial Manual 2016," Plaxis 2016, p. 132, 2016.

[22] T. L. Gouw, "Common mistakes on the application of plaxis 2D in analyzing excavation problems," Int. J. Appl. Eng. Res., vol. 9, no. 21, pp. 8291-8311, 2014.

[23] M. E. Hingga, "IMPLEMENTASI EFFECTIVE STRESS UNDRAINED ANALYSIS DAN EFFECTIVE Total Stress Analysis dan Effective Stress Analysis Undrained dan Drained Material," vol. 4, no. KoNTekS 4, pp. 2-3, 2010. 
[24] R. B. J. Brinkgreve, "Copyright ASCE 200569 Soil Constitutive Models Evaluation, Selection, and Calibration," Geo-Frontiers Congr. 2005, pp. 69-98, 2005.

[25] K. S. Ti, B. B. Huat, S. Noorzaei, S. Jaafar, and G. S. Sew, "A review of Basic Soil Constitutive Models for Geotechnical Application," Electron. J. Geotech. Eng., vol. 97, no. 2, pp. 375-391, 1971.

[26] J. F. Labuz and A. Zang, "Mohr-Coulomb failure criterion," Rock Mech. Rock Eng., vol. 45, no. 6, pp. 975-979, 2012, doi: 10.1007/s00603-012-0281-7. 